\title{
Risk Factors of Patent Ductus Arteriosus in Preterm
}

\author{
Anak Agung Made Wijaya Kusuma*, Eka Gunawijaya, I Gusti Ngurah Sanjaya Putra, \\ Ni Putu Veny Kartika Yantie, I Made Kardana, I Made Gede Dwi Lingga Utama, \\ I Wayan Gustawan
}

Department of Child Health, Udayana University Medical Faculty/Sanglah Hospital, Denpasar, Bali, Indonesia

\section{Email address:}

aamadewijayakusuma@gmail.com (A. A. M. W. Kusuma), ekagunawijaya@yahoo.com (E. Gunawijaya), sanjayaputra65@gmail.com (I G. N. S. Putra), kartika.veny@gmail.com (N. P. V. K. Yantie), made_kardana@yahoo.com (I M. Kardana), dwi_lingga09@yahoo.com (I M. G. D. L. Utama), iwayangustawan@gmail.com (I W. Gustawan)

${ }^{*}$ Corresponding author

\section{To cite this article:}

Anak Agung Made Wijaya Kusuma, Eka Gunawijaya, I Gusti Ngurah Sanjaya Putra, Ni Putu Veny Kartika Yantie, I Made Kardana, I Made Gede Dwi Lingga Utama, I Wayan Gustawan. Risk Factors of Patent Ductus Arteriosus in Preterm. American Journal of Pediatrics.

Vol. 6, No. 2, 2020, pp. 168-172. doi: 10.11648/j.ajp.20200602.29

Received: March 14, 2020; Accepted: April 7, 2020; Published: April 29, 2020

\begin{abstract}
Patent Ductus Arteriosus (PDA) is one of acyanotic congenital heart diseases that often occurs in preterm infants and closely related to an increased risk of complications for sufferers. Identification of PDA risk factors in preterm infants is very important, so that the diagnosis and management can be done earlier. In this study we aimed to determine risk factors of PDA in preterm infants. This case-control study was conducted between July 2017 and April 2018, analysed 43 preterm infants with PDA as the case group and 43 preterm infants without PDA as the control group. The basic information related to characteristics, risk of infection and perinatal history in both groups were collected. Bivariate and multivariate analysis with logistic regression were performed to identify risk factors for PDA. We found several factors were identified significantly $(\mathrm{P}<0.05)$ as risk factors for PDA including premature rupture of membranes $>12$ hours (OR 7.25; 95\% CI: $2.08-25.09)$ and thrombocytopenia in the first 24 hours (OR 15.11; 95\% CI: 3.73 - 61.13). This study concluded premature rupture of membranes $>12$ hours and thrombocytopenia in the first 24 hours were proven to increase the risk of PDA in preterm infants.
\end{abstract}

Keywords: Risk Factor, PDA, Preterm, Thrombocytopenia, Premature Rupture of Membranes

\section{Introduction}

World Health Organization (WHO) noted that the incidence of preterm births in Indonesia in 2010 was 15.5 per 100 live births which ranked Indonesia as $9^{\text {th }}$ highest among 184 countries. In addition, if compared with other ASEAN countries, Indonesia has the highest incidence of preterm birth. Nearly one million infants die each year from preterm birth complications [1]. Patent Ductus arteriosus (PDA) is one of acyanotic congenital heart disease which has a high incidence in preterm birth [2].

A recent study in Iran has identified several risk factors associated with PDA, including: young gestational age, low birth weight, asphyxia and respiratory distress syndrome [3] The weaknesses of the study were carried out in a crosssectional design, so that the causal relationship of the variables couldn't be investigated further. Sepsis is one of the risk factors for PDA. Premature rupture of membranes $>12$ hours is a risk factor for infection and neonatal sepsis, but its relationship as a risk factor for PDA in preterm infants has not been studied. A retrospective study of preterm infants showed that thrombocytopenia was an independent factor in the occurrence of PDA [4].

Meanwhile other study in Berlin-Germany showed thrombocytopenia in the first 24 hours did not associated with the occurrence of PDA in preterm infants [5]. The difference between those results urge the need for further research to prove thrombocytopenia as a risk factor for PDA. Research about PDA risk factors in preterm infants has never been carried out in Indonesia, so a study is needed to identify several risk factors in order to support the results of existing studies and correct weaknesses of previous studies. 


\section{Mmaterials and Method}

This case control retrospective study was conducted in the neonatal care level I, II, III Sanglah Hospital Denpasar, started from July 2017 to April 2018 to find out some of the risk factors for PDA. The inclusion criteria in this study including: preterm infants (gestational age $<37$ weeks), parents agreed to participate in the study (proven by the signing of the informed consent) and suffered from isolated PDA from echocardiographic examination (specifically for case groups). Exclusion criteria included no routine blood examination data in the first 24 hours of life, incomplete medical records, infants with major congenital abnormalities, or with suspicion/ confirmed of congenital syndrome (including congenital rubella syndrome).

The research sample was taken by consecutive sampling method. The flow of the study is explained in Figure 1. Data analysis in this study consisted of descriptive statistical analysis, bivariate analysis and multivariate analysis. The statistical test used in the bivariate analysis was the Chisquare test with alpha limit 0.05 . Multivariate analysis was performed by using logistic regression test.

The association value was counted by adjusted odd ratio, while statistics value by $95 \%$ confidence interval and $\mathrm{P}$ value. All data were processed by using computer program. This study has been approved by the Research Ethics Committee from Faculty of Medicine Udayana University/ Sanglah Hospital.

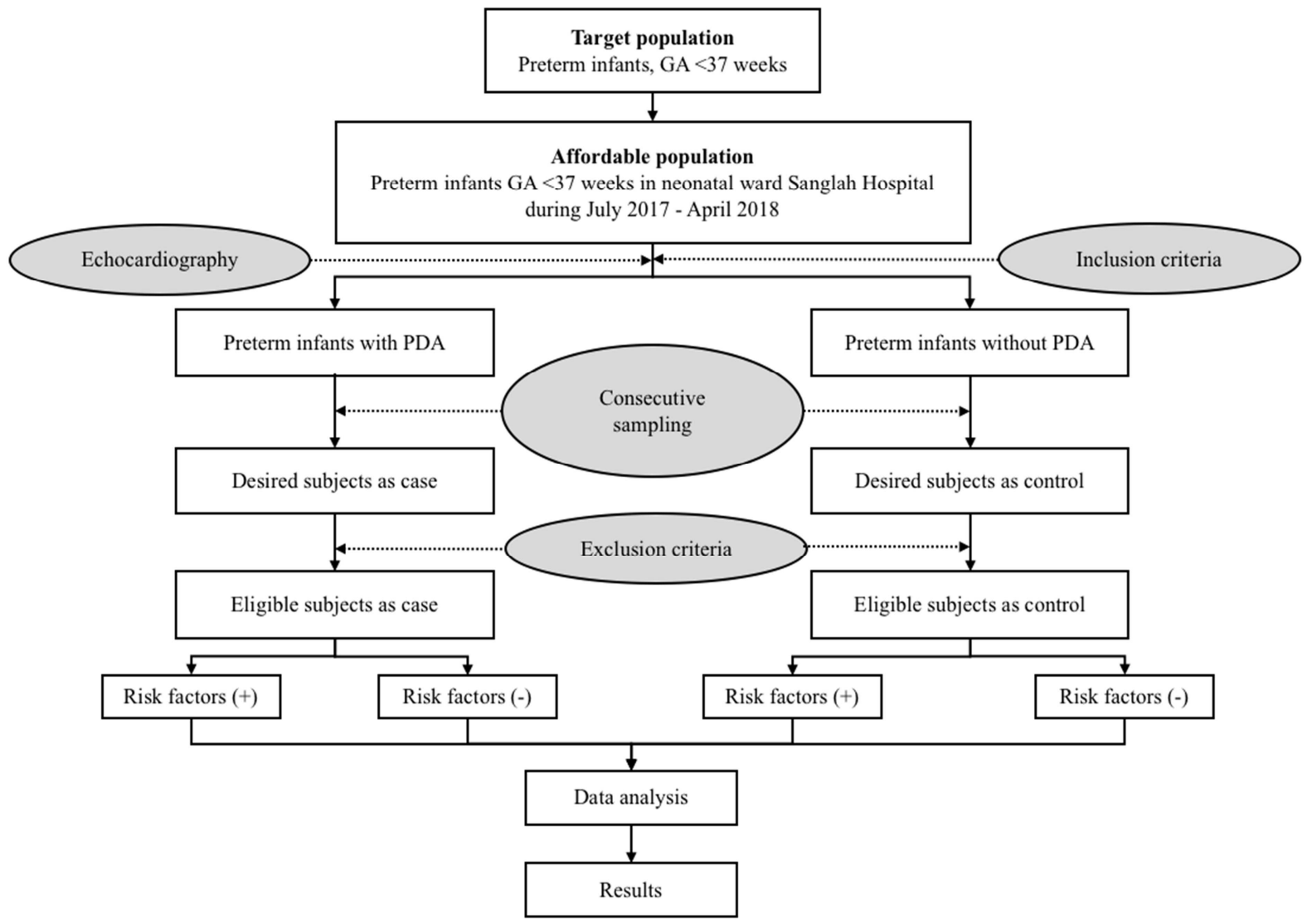

Figure 1. The flow of study.

\section{Results}

Among 108 infants, only 86 infants were included in the analysis according to the sample size calculation and divided evenly into case and control groups. The basic characteristics of the study sample were shown in Table 1.

Table 1. Characteristics of subjects.

\begin{tabular}{lll}
\hline Characteristics & PDA (n=43) & No PDA (n=43) \\
\hline Gender, girl (\%) & $24(55.8)$ & $21(48.8)$ \\
Age (day), mean (SD) & $3.6(0.8)$ & $3.4(0.8)$ \\
Gestational age (weeks), mean (SD) & $30.8(2.8)$ & $32.1(2.1)$ \\
Birth weight (grams), mean (SD) & $1494.2(435.7)$ & $1575.4(431.6)$ \\
Delivery mode, vaginal (\%) & $26(60.5)$ & $24(55.8)$ \\
\hline
\end{tabular}

\begin{tabular}{lll}
\hline Characteristics & PDA $(\mathbf{n}=\mathbf{4 3})$ & No PDA $(\mathbf{n}=\mathbf{4 3})$ \\
\hline Gemelli, yes (\%) & $3(7.0)$ & $12(27.9)$ \\
Fetal distress, yes (\%) & $5(11.6)$ & $3(7.0)$ \\
Exogenous surfactant, yes (\%) & $13(30.2)$ & $6(14.0)$ \\
\hline
\end{tabular}

Bivariate analysis with Chi Square test to get the variables that affect the incidence of PDA in preterm infants were premature rupture of membranes $>12$ hours, gestational age $<32$ weeks, asphyxia and thrombocytopenia in the first 24 hours. Birth weight $<1500$ grams and respiratory distress syndrome from bivariate analysis were not associated with the incidence of PDA in preterm infants with $\mathrm{P}$ values $>0.2$, so both of these two variables were not included in the multivariate analysis. The results of bivariate analysis were presented in Table 2. 
Table 2. Bivariate analysis of PDA risk factors in preterm infants.

\begin{tabular}{|c|c|c|c|c|c|c|c|c|c|}
\hline \multirow{2}{*}{ Variable } & & \multicolumn{2}{|c|}{ PDA } & \multicolumn{2}{|c|}{ No PDA } & \multirow{2}{*}{$\mathbf{P}$} & \multirow{2}{*}{ OR } & \multicolumn{2}{|c|}{$95 \%$ CI } \\
\hline & & $\mathbf{n}$ & $\%$ & $\mathbf{n}$ & $\%$ & & & Min & Max \\
\hline \multirow{2}{*}{$\begin{array}{l}\text { Premature rupture of } \\
\text { membranes }>12 \text { hours }\end{array}$} & Yes & 33 & 76.7 & 15 & 34.9 & \multirow{2}{*}{$<0.001$} & \multirow{2}{*}{6.16} & 2.39 & 15.85 \\
\hline & No & 10 & 23.3 & 28 & 65.1 & & & & \\
\hline \multirow{2}{*}{ Gestational age } & $<32$ weeks & 26 & 60.5 & 20 & 41.9 & \multirow{2}{*}{0.084} & \multirow{2}{*}{2.12} & 0.89 & 5.02 \\
\hline & $>32$ weeks & 17 & 39.5 & 23 & 58.1 & & & & \\
\hline \multirow{2}{*}{ Birth weight } & $<1500$ grams & 24 & 55.8 & 20 & 46.5 & \multirow{2}{*}{0.388} & \multirow{2}{*}{1.45} & 0.62 & 3.39 \\
\hline & $>1500$ grams & 19 & 44.2 & 23 & 53.5 & & & & \\
\hline \multirow{2}{*}{ Asphyxia } & Yes & 34 & 79.0 & 19 & 21.0 & \multirow{2}{*}{0.001} & \multirow{2}{*}{4.77} & 1.84 & 12.33 \\
\hline & No & 9 & 27.3 & 24 & 72.7 & & & & \\
\hline \multirow{2}{*}{$\begin{array}{l}\text { Respiratory distress } \\
\text { syndrome }\end{array}$} & Yes & 39 & 90.7 & 35 & 81.4 & \multirow{2}{*}{0.213} & \multirow{2}{*}{2.22} & 0.61 & 8.04 \\
\hline & No & 4 & 9.3 & 8 & 18.6 & & & \multirow{3}{*}{3.81} & \multirow{3}{*}{35.44} \\
\hline \multirow{2}{*}{ Thrombocytopenia } & Yes & 26 & 60.5 & 5 & 11.6 & \multirow{2}{*}{$<0.001$} & \multirow{2}{*}{11.62} & & \\
\hline & No & 17 & 39.5 & 38 & 88.4 & & & & \\
\hline
\end{tabular}

The results of the analysis were followed by multivariate logistic regression and showed that the variables of premature rupture of membranes $>12$ hours and thrombocytopenia in the first 24 hours affected the occurrence of PDA in preterm infants (Table 3).

From the data presented in Table 3 , the equation can be calculated to predict the probability of preterm infants to suffer from PDA. The probability of preterm infants with prenatal history of premature rupture of membranes $>12$ hours and thrombocytopenia in the first 24 hours to suffer from PDA was $86.3 \%$. Preterm infants with one risk factor and without risk factors were described in Table 4.

Table 3. Multivariate analysis of PDA risk factors in preterm infants.

\begin{tabular}{|c|c|c|c|c|c|c|c|c|}
\hline \multirow{2}{*}{ Variable } & \multirow{2}{*}{ Coefficient } & \multirow{2}{*}{ S. E. } & \multirow{2}{*}{ Wald } & \multirow{2}{*}{ df } & \multirow{2}{*}{$\mathbf{P}$} & \multirow{2}{*}{ OR } & \multicolumn{2}{|c|}{$95 \% \mathrm{CI}$} \\
\hline & & & & & & & Min & Max \\
\hline Premature rupture of membranes $>12$ hours & 1.982 & 0.637 & 9.676 & 1 & 0.002 & 7.256 & 2.082 & 25.296 \\
\hline Gestational age $<32$ weeks & 0.526 & 0.594 & 0.782 & 1 & 0.376 & 1.691 & 0.528 & 5.419 \\
\hline Asphyxia & 0.978 & 0.579 & 2.853 & 1 & 0.091 & 2.660 & 0.855 & 8.278 \\
\hline Thrombocytopenia & 2.716 & 0.713 & 14.504 & 1 & $<0.001$ & 15.113 & 3.736 & 61.139 \\
\hline Constanta & -2.856 & 0.704 & 16.460 & 1 & $<0.001$ & 0.058 & & \\
\hline
\end{tabular}

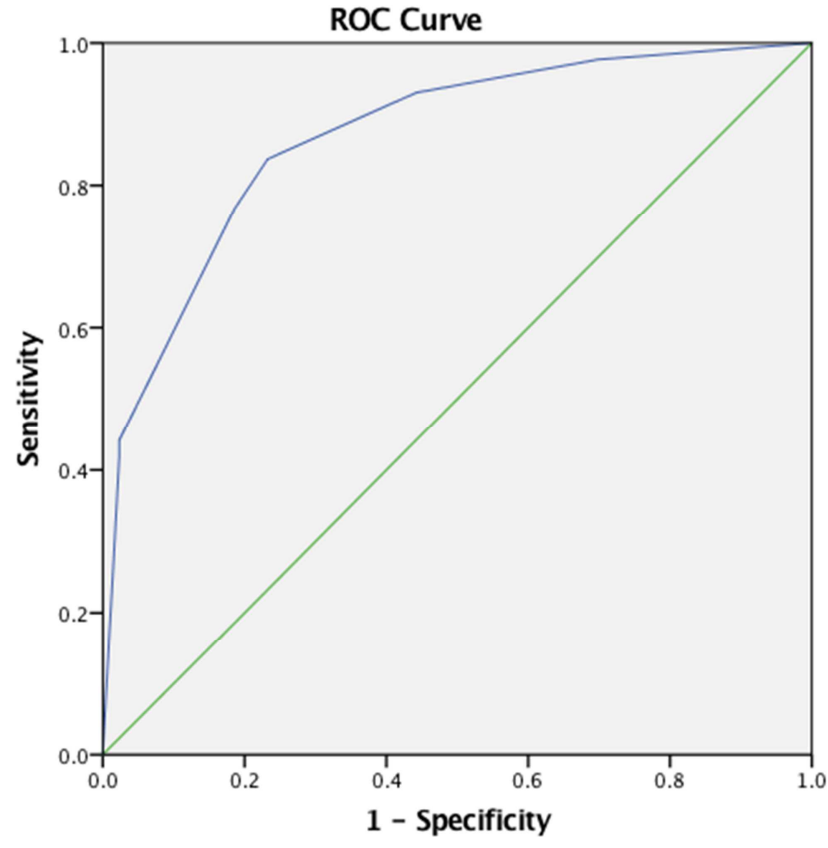

Figure 2. Evaluation of equality quality with discrimination parameters using the area under the curve (AUC).
Table 4. Probability of preterm infants suffer from PDA based on risk factors.

\begin{tabular}{lll}
\hline $\begin{array}{l}\text { Premature rupture of } \\
\text { membranes }>\text { 12 hours }\end{array}$ & $\begin{array}{l}\text { Thrombocytopenia } \\
\text { in 24 first hours }\end{array}$ & Probability (\%) \\
\hline+ & + & 86.3 \\
+ & - & 29.4 \\
- & + & 46.5 \\
- & - & 5.4 \\
\hline
\end{tabular}

The equation was assessed for quality, based on calibration and discrimination parameters. The $\mathrm{P}$ value in the Hosmer and Lame show test was 0.737 which showed the equation had good calibration. Area under the curve (AUC) was used to assess the quality of the equation based on discrimination parameters. The AUC value obtained was $86.8 \%$ which means that the interpretation of equation was statistically satisfying (figure 2).

\section{Discussion}

As many as 43 infants in the case group suffered from PDA, most of them $(55.8 \%)$ were female, which was not statistically significant $(\mathrm{P}>0.05)$. Previous studies showed different results, most of them were male and they were statistically significance $[3,6]$. The mean gestational age in this study was 31.48 weeks with standard deviation 2.53 , the mean birth weight in this study was 1534.77 grams with standard deviation 433.01. Similar results was obtained in a 
study from 2016, with mean gestational age was 32 weeks and mean birth weight was 1700 grams [3].

A study in 2013 showed different result than this study [6]. Gestational age $<32$ weeks from bivariate and multivariate analysis were not proven to influence the occurrence of PDA. Logistic regression analysis of gestational age $<32$ weeks did not significantly affect the occurrence of PDA (OR 1.69; 95\% CI: 0.52-5.41; $\mathrm{P}=0.376$ ). Previous study in Iran had different results. A study involving 200 preterm infants showed the incidence of PDA in preterm infants was $22.5 \%$.

From these data then it can be estimated that the proportion of PDA was $70 \%$ occurred in gestational age $<32$ weeks. Univariate logistic regression analysis showed a significant relationship between PDA and gestational age (OR 0.67; 95\% CI: 0.58-0.77; P <0.001) [3]. This difference was possibly caused by small samples size in this study and we did not recruit term infants as control group.

There were several underlying mechanism of PDA in infants with young gestational age, including oxygen sensitization to duct which less effective so that oxygen fail to induce smooth muscle cell contraction [7, 8]; then sensitivity of prostaglandins and nitric oxide (NO) which result in ductus arteriosus remain open. The sensitivity to prostaglandin and NO in preterm infants occur for a longer period [9].

Study showed that EP4 receptors are very sensitive to prostaglandin and less sensitive to oxygen [10]. Low birth weight occurs frequently with preterm birth. This relationship is also related significantly to the incidence of PDA. This relationship had been proven through research that showed the higher birth weight of preterm infants, would decrease the risk of PDA (OR 0.998; 95\% CI: 0.997-0.999; P <0.001). From these study it can also be estimated that the proportion of PDA in infants with birth weight $<1500$ grams reached to $66.7 \%[3]$.

Our study showed different results. Bivariate analysis of birth weight $<1500$ grams did not find a significant relationship with PDA in our subjects (OR 1.45; 95\% CI: 0.62 - 3.39; $\mathrm{P}=0.388)$. This difference in results was due to differences of the control group in our study. We only compared low birth weight group without including normal weight group. Low birth weight plays role in the pathophysiology of PDA through several mechanisms such as: impaired differentiation, proliferation, migration and contractility of ductus arteriosus due to lack of smooth muscle cell, resulting in failure of ductus arteriosus closure while the baby was borned [7, 11]; the differences in the anatomical structure of ductus arteriosus walls and lumen in normal birth weight infant and infant with low birth weight [12].

Premature rupture of membranes is associated with labour complications, including preterm birth and increased risk of infection that could increase perinatal mortality and morbidity [13]. Infection that occurred before the age of 5 days was a risk factor for PDA (OR 19.1; 95\% CI: 4-90; P $<0.001)$ [14]. Bivariate and multivariate analysis showed premature rupture of membranes $>12$ hours had a significant relationship with the incidence of PDA in our subjects (OR
7.256; 95\% CI: 2.082 - 25.2296; $\mathrm{P}=0.002$ ). Infection caused by premature rupture of membranes will activate inflammatory mediators such as tumor necrosis factor alpha (TNF- $\alpha$ ) which induces prostaglandin and inhibits platelet function [7]. The level of TNF- $\alpha$ would increased when preterm infants with PDA were 5 days old and were positively correlated with prostaglandin level $(\mathrm{r}=0.72 ; \mathrm{P}$ $<0.01)$ [14].

Asphyxia marked by APGAR score $<7$ at the first minute after birth in this study was shown could increase the risk of PDA from bivariate analysis $(\mathrm{P}<0.05)$. Multivariate analysis with logistic regression showed different result (OR 2.66; 95\% CI: $0.85-8.27 ; \mathrm{P}=0.091)$. Likewise the respiratory distress syndrome, which the results of bivariate analysis showed this factor was not proven significantly to affect the occurrence of PDA in preterm infants $(\mathrm{P}=0.213)$.

This result is different from previous study in Iran, which found that decrease APGAR scores will increase the risk of PDA, they found the proportion of asphyxia in the first minute of birth in infants whom experienced PDA was $33.5 \%$. The decrement one point of APGAR score will increase the risk of PDA by $26 \%$ [3]. The difference of the result of this study may be due to differences of operational definitions. Asphyxia and respiratory distress in this study involve moderate and severe degrees, whereas previous studies only involved severe asphyxia and severe respiratory distress. Both of these cause hypoxia and acidosis. The incidence of hypoxia and acidosis were higher in preterm infants, which was due to immaturity of lungs. Hypoxia and acidosis would result in low $\mathrm{PaO}_{2}$ and $\mathrm{SaO}_{2}$ [7]. Hypoxia would cause ineffective oxygen sensitization to ducts that fail to induce smooth muscle cells contraction $[7,8]$.

The final factor that was proven as risk factor for PDA in this study was low platelet count. Analysis of finding low platelet count in the first 24 hours of life would increase the risk of PDA by 15.113 times, compared to preterm infants who did not suffer from thrombocytopenia (95\% CI: 3.73661.139; P <0.001). A retrospective study of 123 infants with 24-30 weeks' gestation showed thrombocytopenia was an independent factor in the occurrence of PDA (OR 13.1; P $<0.0001$ ) [4]. The meta-analysis level study proved a significant relationship between PDA and platelet count $<150$ x $10^{3} / \mu \mathrm{L}$ (6 studies; RR 1.215; 95\% CI: 1.027-1.436); with platelet count $<100 \times 10^{3} / \mu \mathrm{L}$ (5 studies; RR 1.255 ; CI 95\%: 1.034-1.525) [15].

Platelet contribute to the closure of the luminal part of ductus arteriosus with activated platelet accumulation and adhesion along with endothelial cell and CD31 cytokines which would increase smooth muscle cell constriction [7]. There were several weaknesses of this study such as: congenital rubella syndrome was excluded based on clinical signs and symptoms without conducting laboratory investigation as gold standard.

This study did not conduct an analysis of oxygen therapy, traceability of risk factors in this study was conducted retrospectively and confidence intervals were less precise, perhaps because this research was a single centre study. 


\section{Conclusion}

The final factor that was proven as risk factor for PDA in pretems was premature rupture of membranes $>12$ hours and low platelet count in the first 24 hours of life.

\section{Funding}

The authors received no specific grants from any funding agency in the public, commercial, or not-for-profit sectors.

\section{References}

[1] WHO. Preterm birth, 2012; [cited 2012 Nov] Available from: http://www.who.int/mediacentre/factsheets/fs363/en/.

[2] Clyman RI, Couto J, Murphy, GM. Patent ductus arteriosus: are current neonatal treatment options better or worse than no treatment at all? Semin Perinatol. 2012; 36: 123-9.

[3] Pourarian S, Cheriki S, Sharma D, Bijanzadeh F, Farahbakhsh $\mathrm{N}$. Prevalence and risk factors associated with the patency of ductus arteriosus in premature neonates: A prospective observational study from Iran. J Matern-Fetal Neo M. 2017; 30: $1460-4$.

[4] Echtler K, Stark K, Lorenz M, Kerstan S. Platelets contribute to postnatal occlusion of the ductus arteriosus. Nat Med. 2010; 16: $75-82$

[5] Sallmon H, Weber SC, Huning B, Stein A, Horn PA, Metze $\mathrm{BC}$, et al. Thrombocytopenia in the first 24 hours after birth and incidence of patent ductus arteriosus. Pediatrics. 2012; 130: 623-30.

[6] Chen YY, Wang HP, Chang JT, Chiou YH, Huang YF, Hsieh KS. Perinatal factors in patent ductus arteriosus in very lowbirthweight infants. Pediatr Int. 2014; 56: 72-6.
[7] Hamrick SE, Hansmann G. Patent ductus arteriosus of the preterm infant. Pediatrics. 2010; 125: 1020-30.

[8] The' baud B, Michelakis ED, Wu XC, Moudgil R, Kuzyk M. Oxygen-sensitive $\mathrm{Kv}$ channel gene transfer confers oxygen responsiveness to preterm rabbit and remodeled human ductus arteriosus: implications for infants with patent ductus arteriosus. Circulation. 2004; 110: 1372-9.

[9] Antonucci R, Bassareo P, Zaffanello M, Pusceddu M, Fanos V. Patent ductus arteriosus in the preterm infant: new insight into pathogenesis and clinical mana-gement. J Matern-Fetal Neo M. 2010; 23: 34-7.

[10] Fan F, Zhu S, Chen L, Zou Y, Fan L, Kang J. Role of prostaglandin E2 and its receptors in the process of ductus arteriosus maturation and functional closure in the rabbit. Clin Exp Pharmacol Physiol. 2010; 37: 574-80.

[11] Yajima I, Colombo S, Puig I, Champeval D, Kumasaka M, Belloir E. A subpopulation of smooth muscle cells, derived from melanocyte-competent precursors, prevents patent ductus arteriosus. PLoS One. 2013; 8: e 53183.

[12] Hermes-Desantis ER, Clyman RI. Patent ductus arteriosus: pathophysiology and management. J Perinatol. 2006; 26: 14-8.

[13] Simbolon D. Faktor risiko sepsis pada bayi baru lahir di RSUD Curup Kabupaten Rejang Lebong. Buletin Penelitian Kesehatan. 2008; 36: 127-34.

[14] Gonzalez A, Sosenko IR, Chandar J, Hummler H, Claure N, Bancalari E. Influence of infection on patent ductus arteriosus and chronic lung disease in premature infants weighing 1000 grams or less. J Pediatr. 1996; 128: 470-8.

[15] Simon SR, Zogchel L, Bas-Suarez MP, Cavallaro G, Clyman RI, Villamor E. Platelet counts and patent ductus arteriosus in preterm infants: a systematic review and meta-analysis. Neonatology. 2015; 108: 143-51. 